$\begin{array}{ll}\text { Abstracta Iranica } & \begin{array}{l}\text { Abstracta Iranica } \\ \text { Revue bibliographique pour le domaine irano-aryen }\end{array} \\ & \text { Volume } \mathbf{2 9 |} \mathbf{2 0 0 8} \\ & \text { Comptes rendus des publications de } \mathbf{2 0 0 6}\end{array}$

\title{
Les liturgies syriaques. Paris, 2006. (Études syriaques, 3)
}

Christelle Jullien

\section{OpenEdition}

12 Journals

Édition électronique

URL : http://journals.openedition.org/abstractairanica/29762

DOI : 10.4000/abstractairanica.29762

ISSN : 1961-960X

Éditeur :

CNRS (UMR 7528 Mondes iraniens et indiens), Éditions de l'IFRI

\section{Édition imprimée}

Date de publication : 15 mai 2008

ISSN : 0240-8910

\section{Référence électronique}

Christelle Jullien, «Les liturgies syriaques. Paris, 2006. (Études syriaques, 3) », Abstracta Iranica [En ligne], Volume 29 | 2008, document 265, mis en ligne le 15 septembre 2008, consulté le 26 septembre 2020. URL : http://journals.openedition.org/abstractairanica/29762 ; DOI : https://doi.org/10.4000/ abstractairanica.29762

Ce document a été généré automatiquement le 26 septembre 2020.

Tous droits réservés 


\section{Les liturgies syriaques. Paris, 2006. (Études syriaques, 3)}

\section{Christelle Jullien}

Ce troisième ouvrage fait un état de la question des liturgies syriaques; il présente les grandes traditions rituelles, ainsi que les documents qui les consignent (bréviaires, offices, commémoraisons calendaires, anaphores...). Plusieurs articles complémentaires détaillent le déroulement des offices. Ajoutons aussi des études sur les "supports" matériels : manuscrits liturgiques en syriaque, archéologie des églises et organisation spatiale de la liturgie. Un lexique des termes liturgiques syriaques clôt le volume, suivi d'un tableau comparatif des rites des Églises orientales.

\section{INDEX}

Thèmes : 6.3. Autres religions

\section{AUTEURS}

\section{CHRISTELLE JULLIEN}

CNRS - Mondes iranien et indien - Paris 